\title{
EXODUS LUDNOŚCI MUZUŁMAŃSKIEJ DO AZJATYCKIEJ CZĘŚCI IMPERIUM OSMAŃSKIEGO W NASTĘPSTWIE PIERWSZEJ I DRUGIEJ WOJNY BAŁKAŃSKIEJ (1912-1913)
}

\section{Dariusz Faszcza}

(1) http://orcid.org/0000-0001-6579-5463

Akademia im. Aleksandra Gieysztora w Pułtusku

\begin{abstract}
THE EXODUS OF THE MUSLIM POPULATION TO THE ASIAN PART OF THE OTTOMAN EMPIRE IN THE AFTERMATH OF THE FIRST AND SECOND BALKAN WAR (1912-1913)
\end{abstract}

The Balkan Wars of 1912-1913 ended in a catastrophe for the Ottoman Empire. As a result of military operations, $80 \%$ of European territory inhabited by the population of four millions were irretrievably lost. A large number of Muslim refugees appeared in the Asian part of the Empire during and after the military operations. This fact was used by the High Porte to change demographic relations in Thrace and Anatolia. These activities led to construction of a homogeneous state and significantly contributed to economic changes in the areas subjected to the settlement. In the national dimension, they contributed to the development of Turkish nationalism.

Keywords: Balkan Wars, Ottoman Empire, refugees, Young Turks, Anatolia, Thrace.

Słowa kluczowe: wojny bałkańskie, Imperium Osmańskie, uchodźcy, młodoturcy, Anatolia, Tracja.

Tragiczne przeżycia ludności cywilnej są nieodłącznym elementem działań wojennych. Mężczyźni, kobiety i dzieci często są mordowani, giną w wyniku bombardowań, a ich dobytek jest grabiony. Taka postawa wobec cywilów przez długi czas tłumaczona była naturą wojny, rozumianej jako bezpardonowa walka między mieszkańcami wojujących państw ${ }^{1}$. Z czasem pogląd ten uległ zmianie, a wojnę zaczęto postrzegać jako rywalizację armii, z wyłączeniem cywilów. Ta myśl legła u podstaw

${ }^{1}$ H.J. Morg en thau, Polityka między narodami. Walka o potęgę i pokój, tłum. R. Włoch, Warszawa 2010, s. 230. 
starań zmierzających do wprowadzenia zakazów mających poprawić los cywili w czasie konfliktów zbrojnych. Ujęto je w formie konwencji haskich dotyczących praw i zwyczajów wojny lądowej z 1899 i 1907 roku², a później także konwencji o ochronie osób cywilnych podczas wojny z 1949 roku $^{3}$. W praktyce jednak zabijanie cywilów nadal było powszechne, przyjmując w XX wieku postać mordów dokonywanych na wielką skalę. W efekcie „walka z cywilami” stała się integralną częścią wojen i głównym narzędziem ,zarządzania strachem”4.

Nie należy się zatem dziwić, że najpewniejszą formą uniknięcia przemocy ze strony wojsk przeciwnika jest ucieczka. Lęk i obawa o losy najbliższych powodują, że cywile opuszczają miejsce zamieszkania i mimo czyhających na nich niebezpieczeństw udają się w wędrówkę w poszukiwaniu schronienia ${ }^{5}$.

Nie inaczej działo się na Bałkanach, które na przełomie XIX i XX wieku były miejscem dwóch dużych wojen prowadzonych w latach 1876-1878 i 1912-1913, wojny serbsko-bułgarskiej w 1885 roku, wojny grecko-tureckiej w 1897 roku oraz licznych powstań ludności chrześcijańskiej przeciwko władzy sułtana. Ich następstwem było powstanie państw narodowych, a w wymiarze społecznym i kulturowym eliminacja wielowiekowych wpływów kultury muzułmańskiej na Bałkanach. Próbowano to osiągnąc poprzez dokonywanie zmian demograficznych w następstwie fizycznej likwidacji ludności islamskiej lub zmuszenie jej do opuszczenia zamieszkiwanych przez nią ziem ${ }^{6}$.

Celem artykułu jest przedstawienie problematyki exodusu ludności muzułmańskiej w wyniku wojen bałkańskich (1912-1913), a także przybliżenie trudności, z którymi musiała się zmierzyć Wysoka Porta w związku z tym zjawiskiem. Artykuł podejmuje także sygnalnie kwestię roli, jaką odegrali migranci w życiu politycznym, społecznym i gospodarczym państwa osmańskiego.

\section{UCIECZKA}

W 1912 roku, wykorzystując osłabienie Imperium Osmańskiego po wojnie włosko-tureckiej z lat 1911-1912, koalicja państw bałkańskich składająca się z Bułgarii,

\footnotetext{
${ }^{2}$ Dz.U. z 1927 r., nr 21, poz. 163.

${ }^{3}$ Dz.U. z 1957 r., nr 38, poz. 171, załącznik.

${ }^{4}$ H. Münkler, Wojny naszych czasów, thum. K. Matus zek, Kraków 2004, s. 24-25, 31-32.

${ }_{5}^{5}$ Według danych organizacji Amnesty International liczba osób zmuszonych do opuszczenia kraju pochodzenia wynosi obecnie ponad $21 \mathrm{mln}, \mathrm{tj} .0,3 \%$ światowej populacji, Sytuacja uchodźców na świecie, https://amnesty.org.pl/sytuacja-uchodzcow-na-swiecie [dostęp: 23 X 2020 r.].

${ }^{6}$ Emigracja ludności muzułmańskiej z Bałkanów odbywała się w kilku falach począwszy od $1821 \mathrm{r}$. Największą skalę przyjęła w latach 1877-1878, kiedy wyemigrowało ok. 1,25 mln osób. S.B. A kova, Immigrants from the Balkans to Turkey and Immigrant Settlements in Western Anatolia, „International Balkan Annual Conference" 2012, vol. 2, s. 549; J. Mc C arth y, Death and Exile: The Ethnic Cleansing of Ottoman Muslims, 1821-1922, Princeton 1995, s. 87-90.
} 
Serbii, Grecji i Czarnogóry postanowiła zbrojnie odzyskać pozostające od ponad 500 lat w posiadaniu Porty tereny zamieszkałe przez ludność chrześcijańską7.

Nieoczekiwanie dla europejskiej opinii publicznej zapoczątkowana 8 października 1912 roku wojna zmieniła się w pogrom wojsk tureckich ${ }^{8}$, w wyniku czego 30 maja 1913 roku w Londynie podpisano pokój ${ }^{9}$. Nie trwał on jednak długo. Na skutek różnic zdań co do podziału zdobytego terytorium doszło do wybuchu II wojny bałkańskiej. 30 czerwca 1913 roku wojska bułgarskie zaatakowały oddziały serbskie i greckie. Wkrótce do wojny z Bułgarią przyłączyła się Rumunia, a także Wysoka Porta. W tej sytuacji osaczona ze wszystkich stron Bułgaria poprosiła o zawieszenie broni, a 10 sierpnia 1913 roku w Bukareszcie podpisano traktat pokojowy ${ }^{10}$.

Skutki wojen bałkańskich okazały się szczególnie dotkliwe dla Imperium Osmańskiego. Utracono ponad 80\% europejskiego terytorium, które zamieszkiwało 4,2 miliona mieszkańców - to jest około $16 \%$ populacji państwa ${ }^{11}$. Imperium straciło także znaczną część potencjału rolnego oraz dochodów, jako że odebrane prowincje należały do najżyźniejszych i najlepiej rozwiniętych. Zmiana granic spowodowała też napływ uchodźców.

Podstawowym powodem ucieczki ludności muzułmańskiej z Bałkanów był lęk przed greckimi, serbskimi i bułgarskimi okrucieństwami. Żołnierze państw sojuszniczych, członkowie organizacji paramilitarnych, rabusie i chrześcijańscy sąsiedzi dopuszczali się na nich licznych gwałtów. Aktom przemocy towarzyszyły także podpalenia oraz niszczenie obiektów świadczących o ich odrębności kulturowej i religijnej ${ }^{12}$.

Według danych zebranych przez członków międzynarodowej komisji działającej pod auspicjami organizacji The Carnegie Endowment for International Peace jesienią 1912 roku w okręgu Monastyr spalono około 80\% wiosek muzułmańskich ${ }^{13}$. W okręgach Kawala i Drama praktycznie nie było wioski, która by nie ucierpiała

${ }^{7}$ H. Batow ski, Podstawy sojuszu batkańskiego 1912 r. Studium z historii dyplomatycznej 18061912, Warszawa 1939, s. 99-128.

${ }^{8} \mathrm{Na}$ temat wojen bałkańskich: R.C. Ha1l, The Balkan Wars 1912-1913: Prelude to the First World War, London-New York 2000; G. Markov, B"lgariâ v Balkanskiâ s"ûz srê̂u Osmanskata imperiâ 1912-1913, Sofiâ 1989; D.J. Cassavetti, Hellas and the Balkan Wars, London 1914; B. Ratković, M. Đurišić, S. Skoko, Srbija i Crna Gora u balkanskimi ratovima 1912-1913, Beograd 1972; E.J. Ericks on, Defeat in Detail: The Ottoman Army in the Balkans, 1912-1913, Westport-London 2003; R. Rabka, Batkany 1912-1913, Warszawa 2010; R. Rabka, Macedonia - Epir - Albania 1912-1913, Warszawa 2016; A. Krzak, Wojny batkańskie 1912-1913, Warszawa 2017.

${ }^{9}$ Umowa o pokoju między Turcją i Sojusznikami [podpisana w Londynie 17/30 V 1913 r.] [w:] J. Rubacha, A. Malinow ski, A. Giza, Historia Butgarii 1870-1915. Materiaty źródtowe z komentarzami, t. I: Polityka międzynarodowa, Warszawa 2006, s. 113-115.

${ }_{10}$ Umowa o pokoju między Bułgaria z jednej strony a Grecją, Czarnogóra, Rumunia i Serbia z drugiej strony [podpisana 28 VII/10 VIII 1913 r. w Bukareszcie] [w:] J. Rubacha, A. Malinowski, A. Giza, Historia Butgarii 1870-1915, s. 122-126.

${ }^{11}$ E.J. Zürcher, Greek and Turkish Refugees and Deportees 1912-1924 [January 2003], http:// www.transanatolie.com/english/turkey/turks/Ottomans/ejz18.pdf, s. 1 [dostęp: 23 X 2020 r.].

12 N. Buxton, With the Bulgarian Staff, New York 1913, s. 116.

${ }^{13}$ Report of the International Commission to Inquire into the Causes and Conduct of the Balkan Wars, Washington 1914, s. 72. 
z rąk członków bułgarskich oddziałów ochotniczych - komitadżi ${ }^{14}$. Mordy miały miejsce również w Strumnicy, gdzie w wyniku samosądów Serbowie mieli zabić od 3 do 4 tys. cywilów ${ }^{15}$.

Przyczyną śmierci muzułmanów były nie tylko mordy i gwałty, ale także głód oraz choroby spowodowane grabieżami i brakiem żywności. Dokładna liczba wyznawców islamu, którzy stracili życie, nie jest znana, mogło to być nawet 200 tys. osób ${ }^{16}$.

Celem agresorów była nie tylko fizyczna likwidacja muzułmanów, ale także wywołanie strachu i skłonienie ich do ucieczki. Działania te wynikały z jednej strony z realizacji idei jednorodności etnicznej, z drugiej zaś z chęci przejęcia ziemi i dobytku dotychczasowych właścicieli. Realizowano to poprzez niszczenie zabudowań, kradzież zwierząt gospodarskich i żywności ${ }^{17}$, a w momencie zakończenia działań militarnych za pomocą różnego rodzaju rekwizycji ${ }^{18}$.

Innym sposobem była groźba przymusowej chrystianizacji. Grupą, która została poddana szczególnym naciskom, byli Pomacy, muzułmańscy Słowianie posługujący się językiem bułgarskim. Chrystianizację prowadzono, tworząc specjalne komisje, które nakazywały siłą doprowadzać ich do cerkwi, gdzie następnie byli zbiorowo chrzczeni ${ }^{19}$. Szacuje się, że w ten sposób chrześcijaństwo przyjęło około 150 tys. osób ${ }^{20}$.

Wyjazdy muzułmanów rozpoczęły się de facto przed wybuchem I wojny bałkańskiej i były efektem wzrostu napięcia w regionie ${ }^{21}$. W podróż udali się głównie ludzie zasobni i rodziny urzędników państwowych. Zasadnicza fala uciekinierów ruszyła jesienią 1912 roku wraz z pierwszymi informacjami o klęskach armii tureckiej i gwałtach popełnianych przez chrześcijan. Gros uciekinierów przemieszczało się wozami zaprzężonymi w woły lub pieszo, maszerując wzdłuż głównych dróg ${ }^{22}$.

Ze względu na porę roku exodus ludności cywilnej odbywał się w trudnych warunkach. Ciągłe opady deszczu spowodowały, że drogi były rozmiękłe i poruszanie się nimi było utrudnione. Ludzie opuszczali domostwa w pośpiechu, zabierając najpotrzebniejsze rzeczy, przez co wielu z nich nie było przygotowanych do

14 Ibidem, s. 74.

15 Według serbskich danych było to 700-800 osób. Report of the International..., s. 73-74.

16 B.N. Şi imşi r, Bulgaristan Türkleri, İstanbul 1986, s. 207; P. The r, Ciemna strona państw narodowych. Czystki etniczne w nowoczesnej Europie, tłum. T. Gabiś, przedm. W. Borodziej, Poznań 2012, s. 114.

17 J. McCarthy, op. cit., s. 147.

18 A. Halaçoğlu, Balkan Harbi Strasında Rumeli'den Türk Göçleri (1912-1913), Ankara 1994, s. 43 .

19 Report of the International..., s. 156-157.

${ }^{20}$ Z. Çe vi k, The Policies that Bulgarian Government Implemented on the Turkish Population During the Balkan Wars (1912-1913) [w:] Recent Advances in Social Sciences, eds. R. Efe, I. Koleva, M. Öztürk, R. Araba c1, Cambridge 2019, s. 40-41.

${ }^{21}$ Szerzej na ten temat: D. Faszcza, Propaganda eksponująca okrucieństwa podczas wojen batkańskich 1912-1913 [w:] Misja wojska. Strategia i bezpieczeństwo państwa. Szkice o siłach zbrojnych, red. T. Pan ecki, J. S molińs ki, Warszawa 2019, s. 92-93.

22 A. Halaçoğlu, op. cit., s. 61. 
wielodniowego marszu. Sytuację uchodźców dodatkowo utrudniały rekwizycje zwierząt pociągowych i jucznych prowadzone przez wojsko osmańskie oraz brak wiarygodnych informacji i wszechobecna nerwowość. Wszystko to powodowało, że pokonanie trasy z Kirk Kilisse do Konstantynopola liczącej nieco ponad $200 \mathrm{~km}$ zajmowało 17-18 dni ${ }^{23}$.

Pomimo tych niedogodności ludzi do wysiłku mobilizował strach. Tak sytuację na drogach opisał korespondent londyńskiego dziennika „Daily Mail”:

[...] ruchom wojsk przeszkadzają niesłychane masy uciekających z północy na południe wieśniaków tureckich z żonami, dziećmi i całym dobytkiem. Wszystkie drogi i pociągi są zajęte przez uciekinierów. Wielu z nich utrzymuje, że to nie Bułgarzy zdobyli Kirk-Kilisse, a Rosjanie. Rosjan zaś chłop turecki boi się jeszcze na podstawie opowiadań ludzi starszych z 1878 roku. Wtedy to Rosjanie mieli postępować bardzo ostro z muzułmanami ${ }^{24}$.

Obok agresji ze strony żołnierzy sojuszu bałkańskiego i ludności chrześcijańskiej przyczyną dużej śmiertelności wśród uciekinierów były niedożywienie oraz towarzyszące mu choroby w rodzaju tyfusu, duru brzusznego i cholery. Szczególnie duże żniwo zebrała cholera, która została przyniesiona przez wojska tureckie przybyłe z Syrii ${ }^{25}$, a jej ofiarami byli głównie najmłodsi - niemowlęta i dzieci.

Większość cywili kierowała się na południe w stronę Adrianopola i do położonego na wybrzeżu Morza Egejskiego portu w Salonikach. Pozostała część szukała schronienia w Albanii, gdzie udało się około 60 tys. osób, głównie z zachodnich okręgów Kosowa i północnych okręgów wilajetów Monastyr i Janina. Ze względu na panujące w tym regionie ubóstwo możliwości udzielenia pomocy uchodźcom były ograniczone i przyjmuje się, że wielu z nich wkrótce zmarło na skutek wycieńczenia, chorób i głodu ${ }^{26}$.

Uchodźcy z południowych okręgów wilajetów: Kosowo, Manastyr, Janina w dużej liczbie udawali się do miasta i portu w Salonikach ${ }^{27}$. Kilkanaście tysięcy uchodźców zgromadziło się także w położonym na południowy wschód od Salonik mieście portowym Kawala ${ }^{28}$.

Mieszkańcy Tracji szukali schronienia przede wszystkim za murami Adrianopola. Tu przyszło im przeżyć koszmar, jakim było długotrwałe oblężenie, podczas którego przyczyną cierpień na równi z działaniami militarnymi był głód i epidemie ${ }^{29}$.

Miejscem, gdzie uchodźcy szukali schronienia, był także Konstantynopol. Do stolicy Imperium docierali drogą lądową, maszerując wzdłuż wybrzeża lub głównym traktem prowadzącym z Adrianopola. Korespondent dziennika „Le Matin” Stefan Lausane opisał widok uciekinierów w następujący sposób: „Starcy, kobiety i dzieci

${ }^{23}$ Ibidem, s. 48-49.

${ }^{24}$ Cyt. za: Bitwa p. Lule Burgas, „Gazeta Warszawska”, 4 XI 1912, nr 127, s. 3.

${ }^{25}$ Według doniesień prasowych w XI 1912 r. na cholerę zapadało dziennie od 2 do 3 tys. żołnierzy tureckich. Depesze, „Gazeta Warszawska”, 22 XI 1912, nr 145, s. 3.

${ }^{26}$ J. Mc Carthy, op. cit., s. 155.

27 Saloniki, „Dziennik Poznański”, 10 XI 1912, nr 258, s. 2.

28 J. McCarthy, op. cit., s. 155-156.

29 N. İpek, The Balkans, War, and Migration [w:] The Balkan Wars, 1912-1913, and Their Sociopolitical Implications, eds. M.H. Yavu z, I. B lu mi, Salt Lake City 2013, s. 644-645. 
uciekają z pola bitwy, unosząc swe ubogie ruchomości. Czasami po dwudziestu zbiegów ciśnie się na wózku zaprzęgniętym w woły. Pochód ten bolesny tworzy już nieprzerwany łańcuch od pola bitwy do murów Konstantynopola" ${ }^{30}$. W ten sposób do miasta dotarło około 120 tys. uchodźców ${ }^{31}$.

\section{EMIGRACJA}

Zakończenie latem 1913 roku działań zbrojnych i wytyczenie nowych granic państwowych postawily przed uchodźcami dylemat: udać się na emigrację czy też zdecydować się na powrót do swoich wiosek, znajdujących się już w granicach państw bałkańskich?

Duża część od razu zdecydowała się na emigrację. Niemałą rolę w podjęciu takiej decyzji odgrywały wiadomości o prawdziwych lub domniemanych mordach oraz obawa przed kłopotami i poniżeniem ze strony chrześcijańskich sąsiadów.

Druga grupa uchodźców zdecydowała się na powrót. W ich przypadku przywiązanie do miejsca zamieszkania było czynnikiem silniejszym niż obawa o przyszłość. W konfrontacji z nową rzeczywistością wielu z nich nie potrafiło się jednak odnaleźć i z czasem, ulegając presji administracyjnej oraz ekonomicznej, podjęli decyzję o udaniu się na uchodźstwo ${ }^{32}$.

Z emigracją ludności muzułmańskiej związana była także akcja wymiany ludności pomiędzy Imperium Osmańskim a Królestwem Bułgarii. Została przeprowadzona na podstawie podpisanego 29 września 1913 roku protokołu wynegocjowanego podczas dwustronnych rozmów pokojowych. W ramach transferu w okresie czterech lat 48570 muzułmanów z Bułgarii i 46764 Bułgarów mieszkających w granicach Imperium Osmańskiego zostało poddanych „dobrowolnemu przesiedleniu”33.

Na podstawie rejestrów tureckich przyjmuje się, że w latach 1912-1920 Bałkany opuścily 413922 osoby $^{34}$.

${ }^{30}$ Na polu bitwy, „Dziennik Poznański”, 6 XI 1912, nr 254, s. 2.

${ }_{31}$ N. İ e k, op. cit., s. 648.

32 Wśród stosowanych metod można wymienić: nakładanie specjalnych podatków, wywłaszczenia, pozbawienie pracy, przymusową konwersję oraz politykę szkolną. P. Ther, op. cit., s. 117.

${ }^{33}$ H.Y. A ğanoğlu, Osmanlı'dan Cumhuriyete Balkanlar'in Makûs Talihi GÖÇ, İstanbul 2001, s. 121-122; S.P. Ladas, The Exchange of Minorities: Bulgaria, Greece, and Turkey, New York 1932, s. 16-17; V. S toânova, Izslevaniâ na b'lgarite iż Iztočna Trakiâ sled Balkanskite vojni (1912-1945) [w:] Migracii ot dvete strani na b"lgaro-turskata granica: nastedstva, identičnosti, interkulturni vzaimodejstviâ, red. V. Ganeva-Rejčeva, M. Elč inova, M. Zlatkova, N. Vukov, Sofiâ 2012, s. 16-17.

${ }^{34}$ A.J. Toyn bee, The Western Question in Greece and Turkey, London 1922, s. 138; S.P. L a das, op. cit., s. 16, przyp. 11; J. McCarthy, op. cit., s. 160. 
Tabela 1. Liczba muzułmańskich emigrantów z Bałkanów w latach 1912-1920

\begin{tabular}{|c|c|}
\hline Lata & Liczba emigrantów \\
\hline $1912-1913$ & 177352 \\
\hline $1914-1915$ & 120566 \\
\hline $1916-1917$ & 18912 \\
\hline $1918-1919$ & 22244 \\
\hline $1919-1920$ & 74848 \\
\hline Ogółem & $\mathbf{4 1 3 9 2 2}$ \\
\hline
\end{tabular}

Źródło: A.J. Toyn bee, The Western Question in Greece and Turkey, London 1922, s. 138.

Jak widać z przedstawionych danych, największa dynamika wyjazdów miała miejsce podczas pierwszych czterech lat - wówczas to wyjechało niespełna 300 tys. osób. W następnych czterech latach liczba migrantów spadła do około 40 tys., aby ponownie wzrosnąc do bez mała 75 tys. w latach 1919-1920.

Część badaczy uważa, że liczba migrantów mogła być wyższa, niż wskazują na to zapisy urzędników. Nie uwzględnia ona bowiem personnes aisées - osób zamożnych oraz „dzikich” uciekinierów, którzy z różnych powodów nie zostali zarejestrowani. Powoduje to, że w literaturze można znaleźć także liczbę 440 tys. osób ${ }^{35}$. Są też autorzy, którzy z tych samych powodów podają liczbę 500 tys. ludzi ${ }^{36}$, co jednak wydaje się wartością znacznie zawyżoną.

\section{PROBLEMY ZWIAZZANE Z PRZESIEDLENIEM LUDNOŚCI MUZUŁMAŃSKIEJ}

Początkowo Wysoka Porta podjęła starania mające na celu ograniczenie napływu migrantów. Rząd miał nadzieję, że utracone ziemie uda się jeszcze odzyskać, w czym mogłaby się okazać przydatna za mieszkująca tam ludność muzułmańska. Skutkowało to tym, że przez pewien czas wstrzymywano się z publikacją przepisów dotyczących pomocy, które mogłyby zachęcać do emigracji ${ }^{37}$. Działania te nie powstrzymały jednak napływu uchodźców.

Uciekinierzy cały czas gromadzili się w miastach portowych, gdzie poszukiwali sposobu na opuszczenie Bałkanów. Nierzadko musieli oczekiwać wiele tygodni na

${ }^{35}$ Mehmet Şevket Paşa'nin Günlüğü, İstanbul 1988, s. 160; S.B. A k ov a, op. cit., s. 549.

${ }^{36}$ A. Antonia des, Le développement Économique de la Thrace, Athens 1922, s. 217. Ryan Ging e ra s podaje liczbę 509 922, zastrzegając, że obejmuje ona także uchodźców z Cypru, Krety i innych wysp: idem, Sorrowful Shores: Violence, Ethnicity, and the End of the Ottoman Empire 1912-1923, Oxford-New York 2009, s. 35.

${ }^{37}$ U. Er de m, Aşâir ve Muhâcirîn Müdüriyet-i Umûmiyesi (1913-1922), ,Zeitschrift für die Welt der Türken" 2017, vol. 9, no. 1, s. 59. 
statek lub prom, często bez możliwości ugotowania posiłku, schronienia się przed deszczem i zimnem, narażając się na rabunki. 1 września 1913 roku tylko w Salonikach i ich okolicach znajdowało się 135 tys. osób oczekujących na ewakuację ${ }^{38}$.

Zapewnienie transportu uchodźcom przekraczało możliwości tureckich armatorów. Dlatego też władze kraju zwróciły się z prośbą o pomoc do państw europejskich. $\mathrm{Na}$ apel odpowiedziały: Rumunia, Austro-Węgry, Rosja, Włochy, Belgia i Wielka Brytania, które udostępniły statki i promy do przewozu migrantów. Z pomocą pospieszył także kedyw Egiptu, który na pokładzie prywatnego jachtu ewakuował 5 tys. osób z portu w Kawali ${ }^{39}$.

Po dotarciu do portu przeznaczenia i zejściu na ląd uchodźcy poddawani byli kwarantannie. Na ten czas starano się zakwaterować ich w hotelach i gospodach, a kiedy te możliwości się wyczerpały, lokowano ich w koszarach, meczetach i koranicznych szkołach - medresach. Nie zaspokajało to jednak potrzeb, przez co tysiące uchodźców koczowało na ulicach i placach ${ }^{40}$ bądź przebywało w stawianych na obrzeżach miast barakach, namiotach lub budowanych własnym sumptem „,biedadomach" ${ }^{41}$. Mimo to nie udało się uniknąć zachorowań. Ogniska cholery odnotowano w Konstantynopolu, Izmirze, Giresun, Akhisarze, Diyarbakır i Adanie ${ }^{42}$.

Obowiązek zapewnienia uchodźcom środków pierwszej potrzeby leżał w gestii władz miejskich i gminnych. Zadanie to realizowały służby municypalne odpowiedzialne za dostawy żywności i wody, utrzymanie budynków i miejsc użyteczności publicznej oraz dbanie o czystość ulic i bazarów ${ }^{43}$. Na pokrycie kosztów z tym związanych przeznaczono 5\% dochodów gmin, fundusze pochodzące z opłat mostowych, sprzedaży lub dzierżawy gruntów, sprzedaży znaczków, biletów do teatrów, a także środki uzyskane z instytucji wakfu ${ }^{44}$ oraz ze skarbu państwa ${ }^{45}$.

Ważną rolę w udzielaniu pomocy uchodźcom odgrywały także lokalne wspólnoty religijne, co wynikało z jednej z pięciu zasad wiary, jaką jest dawanie jałmużny. Niezależnie od pobierania jałmużny, będącej swoistego rodzaju indywidualnym podatkiem, inicjowały one różnego rodzaju akcje mające na celu pobudzenie dodatkowej ofiarności współwyznawców w kraju i poza jego granicami ${ }^{46}$.

38 Report of the International..., s. 278.

39 J. McCarthy, op. cit., s. 156.

${ }^{40}$ A. Halaçoğlu, op. cit., s. 69.

${ }^{41}$ Według prawa muzułmańskiego ktokolwiek między zachodem a wschodem słońca przykryje dachem ściany domu postawionego na ziemi państwowej, staje się jego właścicielem i nikt nie może go z niego usunąć. Zob. Z. S i e mek, Struktura urbanizacyjna współczesnej Turcji [w:] M. Je rc zyń ski, L.F. Chaves, Z. S i e m e k, Studia nad struktura funkcjonalną miast, Wrocław-Warszawa-Kraków 1973, s. 267, przyp. 4.

42 A. Ha la ço ğlu, op. cit., s. 100.

43 S.J. Shaw, E.K. Shaw, Historia Imperium Osmańskiego i Republiki Tureckiej, t. 2: 1808-1975, tłum. B. Św ietlik, Warszawa 2012, s. 159-161.

${ }^{44}$ Wakf - fundacja religijna lub darowizna, z której dochody przeznaczone są na cele charytatywne. Zob. R. Lew is, op. cit., s. 61-63.

${ }^{45}$ Y. Baytal, Balkanlar'dan Anayurda Yapılan Göçler ve Türkiye Açısından Sonuçları (19121925), ,Turkish Studies” 2018, vol. 13, no. 1, s. 22.

${ }^{46}$ R. Lew is, Życie codzienne..., s. 43; M. Łyszczarz, Znaczenie dobroczynności w doktrynie religijnej islamu wobec specyfiki życia codziennego $w$ kraju niemuzulmańskim na przykładzie polskich Tatarów. Zarys problemu, „Muzułmanie Rzeczypospolitej” 2010, nr 1(5), s. 5. 
W akcję udzielania pomocy uchodźcom włączyła się również utworzona w 1868 roku Organizacja Czerwonego Półksiężyca, której członkowie zapewniali żywność i odzież uchodźcom oraz prowadzili szpitale ${ }^{47}$.

Kwestia docelowego rozlokowania uchodźców stanowiła poważne wyzwanie dla władz, zarówno w kontekście politycznym, jak i organizacyjnym. Klęski poniesione w Trypolitanii i na Bałkanach spowodowały, że to czynniki etniczne, religijne i wojskowe zdecydowały o rozlokowaniu uchodźców ${ }^{48}$. Postanowiono osiedlić ich w rejonach przygranicznych lub zamieszkanych przez mniejszości niemuzułmańskie. Miało to wykluczyć wykorzystywanie w przyszłości argumentów etnodemograficznych w przypadku wystosowania roszczeń terytorialnych przez sąsiednie państwa, a z chwilą wybuchu wojny pozwolić uniknąc „,iosu w plecy” zadanego przez chrześcijan $^{49}$.

Instytucją rządową, która odpowiadała za całokształt prac osadniczych, było Ministerstwo Spraw Wewnętrznych i utworzony w grudniu 1913 roku w jego strukturach Departament do spraw Osiedlenia Plemion i Uchodźców ${ }^{50}$.

Emigrantów z Półwyspu Bałkańskiego w przeważającej liczbie wysyłano do zachodnich regionów Anatolii, gęsto zamieszkałych przez Greków. Rozmieszczeni zostali oni głównie w wilajetach: Aydın, Hüdavendigâr, Sivas, Haleb, Ankara, Konya i Adana oraz w niezależnych sandżakach (okręgach) Karasi i Eskişehir. Ponadto 134 tys. osób zostało osadzonych w przygranicznych okręgach w Tracji, gdzie miasta i miasteczka w dużej liczbie zamieszkiwane były przez niemuzułmańską populację ${ }^{51}$.

Tabela 2. Liczba muzułmańskich emigrantów z Bałkanów w latach 1912-1920 w rozbiciu na wilajety i niezależne sandżaki

\begin{tabular}{|c|c|c|c|}
\hline Wilajet & Liczba uchodźców & $\begin{array}{c}\text { Autonomiczny } \\
\text { sandżak }\end{array}$ & Liczba uchodźców \\
\hline İstanbul & 3609 & İzmit & 6771 \\
\hline Edirne & 132500 & Eskişehir & 9088 \\
\hline Adana & 9059 & Bolu & 258 \\
\hline
\end{tabular}

47 B. Ömer, Hanımefendilere Hilâl-i Ahmer'e Dair Konferans, Ankara 2009, s. 123-124.

${ }^{48}$ Odmienne stanowisko zajmuje Philip Ther, który uważa, że chodziło o ,zaludnienie w tradycyjnym sensie": idem, op. cit., s. 119. W świetle cytowanych ustaleń tureckich historyków teza ta wydaje się jednak błędna.

${ }^{49}$ A. İç du y gu, D. S ert, The Changing Waves of Migration from the Balkans to Turkey: A Historical Account [w:] Migration in the Southern Balkans From Ottoman Territory to Globalized Nation States, eds. H. Vermeulen, M. Baldwin-Edwards, R. van Boeschoten, Heidelberg-New York-Dordrecht 2015, s. 89; E. Ero 1, "Macedonian Question" in Western Anatolia: The Ousting of the Ottoman Greeks before World War I [w:] World War I and the End of the Ottomans. From the Balkan Wars to the Armenian Genocide, eds. H.-L. Ki es er, K. Ökte m, M. Rein kow sk i, London-New York 2015, s. 99 , 104.

${ }^{50}$ Szerzej na ten temat: V. Marttin, Bir Osmanli Kurumunun Adi Ve Etkinliği Üzerine, „Uluslararasi Avrasya Sosyal Bilimler Dergisi” 2011, Say1 5, s. 14-30.

${ }^{51}$ H.Y. A ğanoğlu, op. cit., s. 110. 


\begin{tabular}{|c|r|c|r|}
\hline Ankara & 10008 & Canik & 3875 \\
\hline Aydın & 145868 & Çatalca & 7500 \\
\hline Haleb & 10504 & Karasi & 14687 \\
\hline Hüdavendigâr & 20853 & Biga & 4033 \\
\hline Sivas & 10805 & Kayseri & 6140 \\
\hline Süriye & 3187 & Karahisar & 280 \\
\hline Kastamonu & 257 & Menteşe & 855 \\
\hline Konya & 8512 & Maraş & 5031 \\
\hline Mamuretülaziz & 242 & & \\
\hline Ogółem & $\mathbf{4 1 3 9 2 2}$ & & \\
\hline
\end{tabular}

Źródło: J. Mc C arthy, Death and Exile: The Ethnic Cleansing of Ottoman Muslims, 1821-1922, Princeton 1995 , s. 160 .

Osadzanie imigrantów na nowych ziemiach nie było łatwym zadaniem. Dla większości z nich był to kraj obcy, co mogło prowadzić do nieporozumień na tle ekonomicznym i obyczajowym ${ }^{52}$. Sytuację dodatkowo komplikowało istnienie dużych, zasiedziałych grup ludności chrześcijańskiej, reprezentujących wrogie państwa: Greków w Anatolii, Bułgarów i Greków w Tracji.

Czynnikami sprzyjającymi integracji były natomiast tożsamość religijna uchodźców (wszyscy byli muzułmanami) oraz zainicjowana w tym czasie polityka władz zmierzająca do tworzenia ,gospodarki narodowej”. Termin ten oznaczał wprowadzanie ograniczeń zasad wolnego rynku, rugowanie niemuzułmańskiego kapitału i zastępowanie go muzułmańskim ${ }^{53}$. Realizowano to za pomocą różnych form nacisku: od akcji bojkotu sklepów i warsztatów prowadzonych przez chrześcijan do zastraszania i stosowania przemocy. Doprowadziło to do licznych krwawych incydentów z ludnością grecką, które w dużym stopniu były inspirowane przez lokalnych działaczy partii młodotureckiej ${ }^{54}$. Stan napięcia podgrzewała dodatkowo prasa i masowo kolportowane broszury ukazujące cierpienia muzułmanów zadane im podczas wojen bałkańskich oraz organizowane od 1913 roku „marsze zemsty” ${ }^{55}$. W efekcie tych wydarzeń na początku 1914 roku Anatolię opuściło 163975 Greków, którzy przenieśli się na wyspy Morza Egejskiego lub do Grecji kontynentalnej ${ }^{56}$.

Stosownie do potrzeb państwo starało się udzielić wsparcia uchodźcom. Osadnicy na terenach wiejskich otrzymywali ziemię, zabudowania, narzędzia, materiał

${ }_{52}^{5}$ N. İpek, op. cit., s. 650.

${ }^{53}$ E.J. Zürcher, The Late Ottoman Empire as Laboratory of Demographic Engineering, „Il mestiere di storico" 2009, n. 1, s. 14.

${ }^{54}$ R. Gingeras, op. cit., s. 40; T. Witu ch, Tureckie przemiany. Dzieje Turcji 1878-1923, Warszawa 1980, s. 202; P. Ther, op. cit., s. 120.

${ }_{55}$ D. Faszcza, op. cit., s. 96.

${ }^{56}$ R. Gingeras, Sorrowful Shores, s. 40. 
siewny i zwierzęta hodowlane ${ }^{57}$. Opracowano także program budowy modelowych osad, w których w centralnym miejscu znajdowały się meczet, bazar i plac z fontanną. Jego realizacja ograniczyła się jednak do zbudowania kilku wiosek w Anatolii ${ }^{58}$.

Osadnicy na terenach miejskich mieli pierwszeństwo w zatrudnieniu i możliwość zaciągnięcia na dogodnych warunkach pożyczek na założenie własnej firmy. Formą pomocy emigrantom było także zwolnienie z płacenia niektórych podatków (np. podatku dochodowego, gruntowego, podatku od zwierząt hodowlanych) na okres trzech lat, a także z obowiązku służby wojskowej na okres 10 lat $^{59}$.

Ważną kwestią było także zapewnianie edukacji sierotom i dzieciom emigrantów. Kwestię tę rozwiązano, umożliwiając im naukę w szkołach zawodowych z internatami. Zgodnie z decyzją parlamentu miały one bezpłatny wstęp do wszystkich szkół w Konstantynopolu przez okres siedmiu lat, a poza stolicą przez okres pięciu lat. Otworem dla nich stały również szkoły wojskowe ${ }^{60}$.

\section{WPŁYW UCHODŹCÓW NA ŻYCIE SPOŁECZNE, GOSPODARCZE I POLITYCZNE}

Napływ uchodźców znacząco wpłynął na sytuację demografię Imperium Osmańskiego i doprowadził do zmiany proporcji muzułmanów do mieszkańców innych wyznań w Tracji i Anatolii Zachodniej ${ }^{61}$.

Widoczne zmiany zaszły $\mathrm{w}$ gospodarce. W rolnictwie migranci wpłynęli na unowocześnienie metod produkcji i wzrost różnorodności upraw, popularyzując na przykład uprawę ziemniaków i tytoniu ${ }^{62}$. Uchodźcy przyczynili się także do rozwoju handlu i rzemiosła w miastach. W dużym stopniu to właśnie dzięki nim dochody w Anatolii w krótkim czasie wzrosły o około $60 \%{ }^{63}$.

Innowacje, które zainicjowali uchodźcy, dotyczyły ponadto sfery politycznej. Swoją obecnością wpłynęli na zmianę myślenia części środowisk muzułmańskich, stając się nośnikiem takich idei, jak separatyzm i nacjonalizm turecki ${ }^{64}$. Ich losy były namacalnym dowodem, że idea osmanizmu, głosząca stworzenie ,narodu osmańskiego" łączącego różne narodowości i religie, w konfrontacji z rozwijającymi się w państwach sąsiednich nacjonalizmami nie jest w stanie zapewnić jedności państwa ${ }^{65}$.

57 B. Horvath, Anadolu 1913, İstanbul 2007, s. 48.

${ }^{58}$ F. Dündar, İttihat ve Terakki'nin Müslümanları İskân Politikası (1913-1918), İstanbul 2002, s. $209-214$.

${ }^{59}$ N. İpek, op. cit., s. 652.

${ }^{60}$ H.Y. A $\breve{g}$ a no ğlu, op. cit., s. 240.

${ }^{61}$ N. İ pek, op. cit., s. 653.

${ }^{62}$ Y. Baytal, op. cit., s. 23.

${ }^{63}$ N. İ pek, op. cit., s. 653.

${ }^{64}$ Ibidem.

${ }^{65}$ M. Todorowa, Bałkany wyobrażone, thum. P. Szymor, M. Budzińska, Wołowiec 2008, s. 377 . 
Wielu z nich zasiliło szeregi ruchu młodotureckiego. Oprócz Mustafy Kemala Atatürka, który pochodził z Salonik, wśród 25 członków jego władz 11 pochodziło z Bałkanów, a z 21 zaangażowanych politycznie oficerów 9 urodziło się i wychowało na utraconych ziemiach ${ }^{66}$. Wszyscy w mniejszym lub większym stopniu doświadczyli żalu z powodu utraty domu rodzinnego, czym można tłumaczyć ich zaangażowanie w realizację idei nacjonalistycznych postulujących tworzenie jednolitego państwa narodowego. Wpływy tej grupy były silne także w następnych latach. W okresie od 1923 do 1946 roku 78 emigrantów z Bałkanów pełniło funkcje ministrów, w tym 30 w 3 i więcej rządach ${ }^{67}$.

\section{ZAKOŃCZENIE}

W wyniku wojen bałkańskich muzułmańska dominacja na ziemiach Półwyspu Bałkańskiego dobiegła końca. Było to efektem z jednej strony niepowodzeń militarnych, z drugiej zaś presji politycznej i ekonomicznej państw bałkańskich dążących do realizacji wyidealizowanej wizji państw narodowych, których definicja zakładała jednorodność pod względem etnicznym i religijnym.

Tym samym procesom podlegało także społeczeństwo tureckie, przy czym uchodźcy z Bałkan odegrali rolę katalizatora zmian. Okazali się oni pomocni w narodowym i gospodarczym odrodzeniu po wyniszczających wojnach. Wpłynęli na umocnienie żywiołu muzułmańskiego, przyczyniając się do homogenizacji etnicznej i religijnej społeczności lokalnych. Mieli również wpływ na umocnienie czynnika narodowego w gospodarce i formowanie kadr nowego reżimu politycznego.

Pojawienie się imigrantów z bagażem nie najlepszych doświadczeń miało istotny wpływ na wzrost nastrojów nacjonalistycznych, wyrażających się we wrogim stosunku do ludności chrześcijańskiej. Mając w pamięci upokorzenia i represje, jakich doświadczyli, odreagowywali gniew na niemuzułmańskich sąsiadach, przyczyniając się do napięć na tle religijnym i narodowym. Kierując się chęcią wyrównania doznanych krzywd, zdaniem części historyków imigranci odegrali ważną rolę w eksterminacji narodu ormiańskiego w latach 1915-1916 ${ }^{68}$.

Los muzułmańskich wygnańców z Bałkanów był bardzo trudny. W ramach realizacji nacjonalistycznych praktyk, charakterystycznych dla XX wieku, najpierw zostali zmuszeni do porzucenia rodzinnych stron i doświadczyli upokorzenia oraz poniewierki, aby zaraz potem przyczynić się do powstania nowego, skupionego wokół etnicznego jądra (Anatolia) państwa narodowego - Republiki Tureckiej.

\footnotetext{
${ }^{66}$ E.J. Zürcher, The Late Ottoman Empire..., s. 970.

${ }^{67}$ Idem, The Balkan Wars and the Refugee Leadership of the Early Turkish Republic [w:] The Balkan Wars..., s. 666.

${ }^{68}$ Idem, Macedonians in Anatolia, s. 971-972; T. A kç a m, A Shameful Act: The Armenian Genocide and the Questions of Turkish Responsibility, New York 2006, s. 86-87.
} 


\section{BIBLIOGRAFIA}

\section{Akty prawne}

Konwencja dotycząca praw i obowiązków mocarstw i osób neutralnych w razie wojny lądowej, Dz.U. z 1927 r., nr 21, poz. 163.

Konwencje o ochronie ofiar wojny, podpisane w Genewie dn. 12 VIII 1949 r. Dz.U. z 1957 r., nr 38, poz. 171, załącznik.

\section{Źródła drukowane}

Report of the International Commission to Inquire into the Causes and Conduct of the Balkan Wars, Washington 1914.

Rubacha J., Malinowski A., Giza A., Historia Bułgarii 1870-1915. Materiaty źródtowe z komentarzami, t. I: Polityka międzynarodowa, Warszawa 2006.

\section{Prasa}

„Dziennik Poznański”, 6 XI 1912, nr 254; 10 XI 1912, nr 258.

„Gazeta Warszawska”, 4 XI 1912, nr 127; 22 XI 1912, nr 145.

\section{Wspomnienia}

Buxt on N., With the Bulgarian Staff, New York 1913.

Mehmet Şevket Paşa'nin Günlüğ̈̈, İstanbul 1988.

\section{Opracowania}

A ğanoğlu H.Y., Osmanlı'dan Cumhuriyete Balkanlar'ın Makûs Talihi GÖÇ, İstanbul 2001.

A kça m T., A Shameful Act. The Armenian Genocide and the Questions of Turkish Responsibility, New York 2006.

A k o va S.B., Immigrants from the Balkans to Turkey and Immigrant Settlements in Western Anatolia, „International Balkan Annual Conference” 2012, vol. 2, s. 548-562.

Antoniades A., Le développement Économique de la Thrace, Athens 1922.

Batowski H., Podstawy sojuszu bałkańskiego 1912 r. Studium z historii dyplomatycznej 1806-1912, Warszawa 1939.

B ay tal Y., Balkanlar'dan Anayurda Yapılan Göçler ve Türkiye Açısından Sonuçları (19121925), „Turkish Studies” 2018, vol. 13, no. s. 13-28.

Cass avetti D.J., Hellas and the Balkan Wars, London 1914. 
Çevik Z., The Policies that Bulgarian Government Implemented on the Turkish Population During the Balkan Wars (1912-1913) [w:] Recent Advances in Social Sciences, eds. R. Efe, I. Koleva, M. Öztürk, R. Arabac1, Cambridge 2019.

Dündar F., Ittihat ve Terakki'nin Müslümanları İskân Politikast (1913-1918), İstanbul 2002.

Erdem U., Aşâir ve Muhâcirîn Müdüriyet-i Umûmiyesi (1913-1922), „Zeitschrift für die Welt der Türken” 2017, vol. 9, no. 1, s. 57-80.

Eri cks on E.J., Defeat in Detail. The Ottoman Army in the Balkans, 1912-1913, WestportLondon 2003.

Erol E., "Macedonian Question" in Western Anatolia: The Ousting of the Ottoman Greeks before World War I [w:] World War I and the End of the Ottomans: From the Balkan Wars to the Armenian Genocide, eds. H.-L. Ki e s er, K. Ö kt e m, M. Rein k ow s ki, LondonNew York 2015.

Faszcza D., Propaganda eksponująca okrucieństwa podczas wojen batkańskich 19121913 [w:] Misja wojska. Strategia i bezpieczeństwo państwa. Szkice o siłach zbrojnych, red. T. Pan e cki, J. S molińs ki, Warszawa 2019.

Gingeras R., Sorrowful Shores: Violence, Ethnicity, and the End of the Ottoman Empire 1912-1923, Oxford-New York 2009.

Halaçoğlu A., Balkan Harbi Strasında Rumeli'den Türk Göçleri (1912-1913), Ankara 1994.

Ha11 R.C., The Balkan Wars 1912-1913: Prelude to the First World War, London-New York 2000.

Horvath B., Anadolu 1913, İstanbul 2007.

İçduygu A., Sert D., The Changing Waves of Migration from the Balkans to Turkey: A Historical Account [w:] Migration in the Southern Balkans From Ottoman Territory to Globalized Nation States, eds. H. Vermeulen, M. Baldwin-Edwards, R. van Boeschoten, Heidelberg-New York-Dordrecht 2015.

İpek N., The Balkans, War, and Migration [w:] The Balkan Wars, 1912-1913, and Their Sociopolitical Implications, eds. M.H. Yavuz, I. Blumi, Salt Lake City 2013.

Krzak A., Wojny batkańskie 1912-1913, Warszawa 2017.

Lad a s.P., The Exchange of Minorities: Bulgaria, Greece, and Turkey, New York 1932.

Lew is R., Życie codzienne w Turcji osmańskiej, tłum. W. Ra dw ań s ki, Warszawa 1984.

Łyszczarz M., Znaczenie dobroczynności w doktrynie religijnej islamu wobec specyfiki życia codziennego $w$ kraju niemuzutmańskim na przykładzie polskich Tatarów. Zarys problemu, „Muzułmanie Rzeczypospolitej” 2010, nr 1(5), s. 5-6.

Mark ov G., B"lgariâ v Balkanskiâ s"ûz srê̂̀u Osmanskata imperiâ 1912-1913, Sofiâ 1989.

Marttin V., Bir Osmanli Kurumunun Adi Ve Etkinliği Üzerine, „Uluslararasi Avrasya Sosyal Bilimler Dergisi” 2011, Say1 5, s. 14-30.

McCarthy J., Death and Exile: The Ethnic Cleansing of Ottoman Muslims, 1821-1922, Princeton 1995.

Morgenthau H.J., Polityka między narodami. Walka o potęge i pokój, thum. R. Włoch, Warszawa 2010.

Münkler H., Wojny naszych czasów, tłum. K. Matuszek, Kraków 2004.

Ö me r B., Hanımefendilere Hilâl-i Ahmer'e Dair Konferans, Ankara 2009.

Rabka R., Batkany 1912-1913, Warszawa 2010.

Rabka R., Macedonia - Epir - Albania 1912-1913, Warszawa 2016.

Ratković B., Đurišić M., Sk ok o S., Srbija i Crna Gora u balkanskimi ratovima 19121913, Beograd 1972.

Shaw S.J., Shaw E.K., Historia Imperium Osmańskiego i Republiki Tureckiej, t. 2: 18081975, thum. B. Św i etlik, Warszawa 2012. 
Si e mek Z., Struktura urbanizacyjna współczesnej Turcji [w:] M. Jerc zyńs ki, L.F. Chaves, Z. Si e mek, Studia nad struktura funkcjonalna miast, Wrocław-Warszawa-Kraków 1973.

Ş i mş ir B.N., Bulgaristan Türkleri, İstanbul 1986.

S toân ova V., Izslevaniâ na b'lgarite iż Iztočna Trakiâ sled Balkanskite vojni (1912-1945) [w:] Migracii ot dvete strani na b"lgaro-turskata granica: nastedstva, identičnosti, interkulturni vzaimodejstviâ, red. V. Ganeva-Rejčeva, M. Elč inova, M. Zlatkova, N. Vukov, Sofiâ 2012.

Th er P., Ciemna strona państw narodowych. Czystki etniczne w nowoczesnej Europie, thum. T. Gabiś, przedm. W. B orodziej, Poznań 2012.

To dor ow a M., Bałkany wyobrażone, thum. P. S zy mor, M. Budzińs ka, Wołowiec 2008. Toyn bee A.J., The Western Question in Greece and Turkey, London 1922.

Wituch T., Tureckie przemiany. Dzieje Turcji 1878-1923, Warszawa 1980.

Zürcher E.J., Macedonians in Anatolia: The Importance of the Macedonian Roots of the Unionists for their Policies in Anatolia after 1914, „Middle Eastern Studies” 2014, vol. 50, no. 6, s. 960-975.

Zürcher E.J., The Balkan Wars and the Refugee Leadership of the Early Turkish Republic [w:] The Balkan Wars, 1912-1913, and Their Sociopolitical Implications, eds. M.H. Yavuz, I. B lu mi, Salt Lake City 2013.

Zürcher E.J., The Late Ottoman Empire as Laboratory of Demographic Engineering, „Il mestiere di storico” 2009, n. 1, s. 7-18.

\section{Źródła internetowe}

Sytuacja uchodźców na świecie, https://amnesty.org.pl/sytuacja-uchodzcow-na-swiecie [dostęp: 23 X 2020 r.].

Zürch er E.J., Greek and Turkish Refugees and Deportees 1912-1924, January 2003, http:// www.transanatolie.com/english/turkey/turks/Ottomans/ejz18.pdf [dostęp: 23 X 2020 r.]. 
